\title{
FETISHISTIC DISAVOWAL AND ELUSIVE JOUISSANCE: THE CASE OF THE SOUTH AFRICAN HIGHER EDUCATION DECOLONISATION PROJECT
}

\author{
S. M. Maistry
}

School of Education

University of KwaZulu-Natal

Durban, South Africa

e-mail: maistrys@ukzn.ac.za

\section{ABSTRACT}

The argument is made that attempts at decolonising higher education as a transformative project in an era of a toxic, exponentially strengthening neoliberal performativity is inherently paradoxical, as any new "reconstitution" is bound to remain ensnared within the neoliberal grand narrative. Such reconstitution will produce new (dis)guises, as in their quest to acquiesce institutions engage in a superficiality that might obfuscate "authentic" transformation. Any kind of transformation is likely to render futile and instantly obsolete the very benchmarks by which we might recognise its manifestation. Its cognitive comprehension sustains a perpetual elusiveness, its realisation an unattainable jouissance, as a positivist predetermination of the precise co-ordinates of decolonisation's outcome is likely to render the transformative project vacuous. The decolonisation enterprise and illusions of its comprehensibility are thus marks of our incomprehensibility; its absolute apprehension can only be our realisation of its non-apprehensibility. Quick-fix, knee-jerk knowledgeability necessarily essentialises complexity, the consequence of which is degenerative, dilutive concoctions in the name of appeasement. True decolonisation necessarily self-determines its yardsticks for evaluation, as it is precisely in its fluid (de)colonised outcomes that its "neocolonisation" with all its frailties is revealed. True transformation and decolonisation in the Foucauldian sense is only possible through a significant discursive event, a rupture of unimaginable proportion, a Žižekian "self-destructive" purification. Anything less will simply reinforce colonialism's normalcy, thereby reducing any "emancipatory" initiative to a farcical "fetishistic disavowal".

Keywords: decolonisation, transformation, rupture, neoliberalism

\section{INTRODUCTION}

"I am already eating from the trash can all the time. The name of this trash can is ideology. The material force of ideology is that it makes me not see what I am effectively eating" (Interview: Žižek 2016). 
This declaration by contemporary Slovenian philosopher and cultural critic, Slavoj Žižek, is indeed profound as it brings into sharp focus the powerful effect of the subliminal and the less overt. Of significance is that our immersion (in ideology) is so "natural" that it renders us blind to the toxicity of what we consume in the social spaces we occupy. In this article I draw attention to two powerful ideological discourse machineries at play in the South African education context, and how blissful obliviousness thereof might render the decolonisation and transformation agenda benign. The first of these is the absorption/assumption/imposition of a neoliberal doctrine and its associated performative discourse into the multiple dimensions of the academic space, and how decolonisation and transformation initiatives appear circumscribed within neoliberal parameters of (im)possibility. The second gains its currency from the State's nationalistic, social cohesion imperatives that manifest in the creation of an ethos of fake political correctness and false congeniality, a context that offers fertile ground for selective appropriations by the expedient of the decolonisation and transformation agenda. I reflect on instances of opportunism and brazen prejudice in the South African higher education space and their implications for the broader social justice project.

I want to argue that the theme of the recent South African Education Research Association (SAERA) conference (2017) and this special edition was a noble attempt to broach a dormant national imperative that has recently been awakened from a hibernation of more than two decades. While some might argue that this "animal" has arisen with much pent-up energy and ready for combat, others might contend that this imperative has weakened somewhat, as attempts at decolonisation (of the curriculum as "concept" and as "practice") are likely to suffer the disappointment that might manifest in the face of the resilience and (im)permeability of traditional canons as to what counts as the epistemological authentic. It might well be nearimpossible to dislodge the entrenched, traditional guardians and custodians of knowledge.

The "decolonisation project" at best is likely to reveal the elusiveness of this noble agenda, at worst it may assume narrow, mechanistic and superficial understandings that might fall prey to degenerative performative (tick-box) trappings that appear to have come into vogue in recent years. True emancipatory praxes in the Freirean sense (Freire 1998) and tangible redistributive outcomes located in the promised "apartheid dividends" might well remain elusive, as decolonisation debates and initiatives remain distinctly circumscribed within the neoliberal grand metanarrative. Hence the search for an ecstatic nirvana, a jouissance (Zizek 2008) through this current wave of delusional over-optimism is likely to unravel as the decolonisation "project" traverses the precarious South African higher education terrain. 


\section{POST-“LIBERATION” NEOLIBERAL STEALTH}

It has become abundantly clear that the honeymoon period in South Africa's young and immature democracy is over. The miracle of free elections was indeed unimaginable. More importantly - and more unimaginable - is that the people's darling social movement, the African National Congress, would morph so rapidly into utter anarchy towards a new kind of totalitarianism driven by capitalist gluttony across the racial spectrum (Habib 2013).

So what went wrong? It was clear that in the post-liberation state the people were full of what Žižek refers to as "immature utopian expectation” (Žižek 2011). As an advanced phase of capitalism, as a discourse and as governmentality, the neoliberal doctrine has progressed with remarkable stealth and conviction, fuelled by political (and economic) agents that appear hypnotised by its allure. Instead of the promised welfare state, where education, health and social security are standard, basic expectations, the country has systematically embraced the values of a neoliberal order (Bond 2011) through powerful modes of what Žižek refers to as ideological obfuscation (Žižek 2011). In other words, the concealment in plain sight of deliberative hegemonic practices, when basic social provisions are reduced to the realms of the market, in which only the economically endowed are best serviced.

It is without contention that the neoliberal doctrine has firmly asserted itself both globally and in the local South African context (Harvey 2007; Bond 2014), and it has done so with such remarkable efficiency and subtlety that it even has the power to hijack/co-opt moves to advance decolonisation and transformation initiatives. This was, for example, evidenced in the blissful, paradoxical utterances of the senior manager of the host institution who in his welcome address to the audience proudly advertised his own pledge and allegiance to the decolonisation agenda, an agenda firmly couched within a neoliberal discourse. He proudly announced that transformation and decolonisation are one of the key performance objectives that his university has set for him - and as can be expected, there are likely to be key checklists, quantifiables and “deliverables" as evidence of his performance as measured by his subordinates' performances.

A defining feature of neoliberal capitalism, especially as it plays out in the South African context is its flagrant socio-economic exclusionary outcomes and palpable economic apartheid. I argue that in attempting to understand the decolonisation agenda that has returned to vogue in recent times, it is crucial that we are sufficiently alert to the ideological milieu within which these debates are unfolding. Of concern is that transformation and decolonisation debates appear to happen with somewhat casual analysis of how the reigning metanarrative has "invisibly" shaped and continues to shape the national economic landscape, and the higher education landscape in particular. This neoliberal metanarrative has systematically reduced almost every sphere of economic and social life (including education) to the logic of the market, 
and its discourse has infused our collective psyche though the systematic normalising of its value system.

David Harvey's insights are useful here as he reminds us that while we are in an era where "the ideals of human rights have moved centre-stage" (Harvey 2008, 23), as we aspire to construct a better world the discourse has been ineffective in challenging the hegemony of the market. Of note is that private property rights and the right to profiteering take precedence over other rights and social justice concerns (Harvey 2010a; b), and certainly over decolonisation. A raw materialism continues to dominate the rationale for all of our economic activities. It becomes clear that neoliberal capitalism's preoccupation with individual freedom for profiteering and personal wealth accumulation might well be in tension with transformation and decolonisation. Of note though is that neoliberalism marks a process where the bourgeoisie enter the political community, requiring the State to protect their property rights as well as to create an economic system where superfluous capital creates superfluous labour - a condition that renders perennial poverty. This is a classical condition where wealth begets wealth (Pogge 2010).

One might well draw a parallel to the South African higher education decolonisation agenda - where bourgeoisie academics of oppressive genesis now infiltrate the social justice and transformation space, hijacking debates, posturing and sometimes overtly attempting to maintain their hegemonic grip on the academic space. To what extent are we prepared to tolerate a selfish, selective mentality that pervades all this debate? To what extent are advocates (especially the highly vocal ones) complicit in strangling the social justice project while engaging the rhetoric of transformation and decolonisation?

A very likely criticism of this argument is the "absence" of tangible evidence for this assertion. However, Foucault reminds that power and hegemony are such that their presence in plain sight is often invisible to the (non)-discerning eye (Foucault 2001). Renowned postcolonial theorist Edward Said's useful insight, as it relates to positioning when one analyses a contentious context in which one is immersed, is to attempt to oscillate between perigee (point of proximity and intimacy) and apogee (distance and elevation, a dissociated fringe position) (Said 1985,12). To adopt a desituated posture allows me to critique more cogently what looks normal and acceptable. My proximity and intimacy come from my lived experience as academic in South African higher education. It allows me to serve as "expert witness" as I use my lived experience as a source of rich "data", even during times when I feel alienated from this community; those moments when the contradictions become insurmountable and threaten to derail my intellectual being. I use these as critical moments in my practice as academic as I adopt a dissociated fringe position, a position that enables me to desituate (to stand outside) and 
examine from a "distance". It is a position that comes with much personal anguish, and as I sought counsel from trusted colleagues in academia I was reminded that I would be traversing a prickly terrain; such a piece would be risky and difficult to write.

At an institutional level neoliberalism as discourse has become pervasive, resembling a normalcy, a natural cultural affinity, an "evolutionary" density of viewing and understanding the social and economic world. The performance model with a surveillance culture has solidified. The university rankings regime that that is now firmly entrenched in the international and national academic arena is a distinctly neoliberal instrument of control. Its ripple effects translate right down to how knowledge as marketable product is packaged and transmitted at the metaphorical university classroom "chalk face", where the performative dimension of teaching and learning supplant the traditional Humboltian notion of a pedagogy and scholarly endeavour (Shore 2010).

The question then is can we reconcile this neoliberal value system that we appear to be "locked into" and the transformation and decolonisation project? In essence, then, there is the realisation that recent initiatives in this regard are necessarily happening within the wellcircumscribed contours of a grand, existing neoliberal blueprint.

\section{NAVIGATING A SOUTH AFRICAN HIGHER EDUCATION SPACE FRAUGHT WITH TENSIONS}

A first precarious point of departure in embarking on the decolonisation project is that there is even a likelihood that the extremely diverse South African academic fraternity would, get anywhere close to a metaphorical "singing out of the same hymn book". Individuals, even those within the same institutions or academic departments, necessarily occupy different points on the proclivity for social justice and redress continuum as a result of their lived experience, socialisation, race, and relative position of privilege. Individuals might find that they are either to the left or the right of each other on this continuum, but very seldom on exactly the same spot.

While this may present as an obvious point, it is that we hold wide-ranging perspectives as to the conceptualisation of and need for decolonisation and transformation that creates tension and discomfort. Of particular note is that individuals have experienced our history and have constructed identities in subjectively peculiar ways. This is why, for example, the search for a single ideological unity through national social cohesion initiatives will always remain elusive - a dead-end positivist aspiration. It is precisely these peculiarities and decentred subjects that have to give effect to the transformation and decolonisation agenda. This warrants a critique of the urge or the search for convergence. The decentred subject necessarily implies 
that every idea/thought is essentially a site for difference/divergence as opposed to convergence, a permanent state of fluidity and flux, to understand this space as anticipating the unanticipated - as a process of perpetual rupture, creation and recreation. In essence then, it recognises and affirms difference and uncertainty. Yet we seem to be preoccupied with the search for convergence or uniform understandings of transformation and decolonising.

In attempting to understand the sites of implementation or application of any decolonisation enterprise it might be useful to recognise that we are dealing with loosely connected parts; it is about understanding the local, the fragments, the sub-components. Higher education institutions (HEIs), for instance, comprise relatively loosely connected fragments, each with its own internal splinters (including faculties, schools, departments, disciplines, staff and students), which is likely to render the search for a unifying discourse of decolonisation particularly elusive. This necessarily implies that we have to understand the very contingent nature of the decolonisation enterprise, and desist from a search for immediate commonality or an "ideological glue" that must bind us together in some kind of cohesive harmony.

At my university we regularly hear the comment that "We need to develop a common understanding of what decolonisation means so that we might develop some effective policy for its implementation". This sentiment is probably common across institutions attempting to formulate definitive policies and plans for its implementation. This is a classic positivist orientation - that we might be able to determine the co-ordinates of our efforts with a high degree of certainty. When we attempt to "decolonise" the curriculum, the university and society it is not as if we are dealing with tangibles that we can readily identify and alter. If anything, it has to do with the fragmented psyche of the individual. The question then is to what extent might the decolonizing and transformation enterprise be essentially an individual enterprise? What is the extent of each individual's personal (de)colonised state or cognitive schema as each projects or speculates a decolonisation and transformation, and how might we get to an understanding of this?

That South African academics are reluctant to engage the issues of race and historical privilege as well as new privilege is a reality that continues to plague and stifle any kind of authentic encounter. This remains a major hurdle that will continue to haunt the South African higher education context. While the Truth and Reconciliation Commission's attempts at healing the nation and sowing the seeds of social cohesion were at best superficial and selective (Oloyede 2009), the rank and file average South African (academic) has not had the opportunity to deliberate in any substantive way as to how we might learn to coexist in an integrated society. So, while there is no textbook or recipe for how this might play itself out, elements of racial suspicion, perceptions of racial competence and affirmative employment policies continue to 
be issues that require robust interrogation. This might well explain why it has become so difficult for the decolonisation project to move forward.

One speaker at the conference bluntly (and with a hint of "mild" hostility) declared his Khoisan ancestry, commenting that unlike other colonised nations of the world, in the South African context the colonisers remained and did not repatriate back to their home countries. This utterance created visible unease in the audience. He went on to request the restitution of the lucrative Stellenbosch wine farms as a first sign of a genuine commitment to the transformation and decolonisation project. This stimulated a tense, but unfortunately very brief discussion, arguably the defining critical incident of the conference, and a stark contrast to the "fake" congeniality that characterised other decolonisation discussions. The key point that did not receive attention though is that through an extended period of apartheid governance the colonisers systematically constructed an economic, cultural, language and intellectual hegemony that remains pervasive.

Arendt reminds us that the kind of imperialism that beset South Africa was somewhat different from that of other colonised countries like the United States of America and Australia, that the capitalist-racist-politico complex was a key mechanism that both sanctioned racial domination and created the strategic political conditions for selective racial economic advancement (Arendt 1973). European colonialism has etched permanent marks on the face of the earth and its people over the last five centuries - generational scars (on both the colonisers and the colonised) that one might consider almost unerasable. Of particular significance is that this scarring has occurred with intensity, consistency and systematic impunity over an extended period of time. The enormity and extent of this hegemonic "stranglehold" is arguably a compelling factor that is likely to determine how and in what direction decolonisation debates are likely to proceed. This issue has been notoriously difficult to broach in the academic space in any critical and constructive manner, and is often avoided or casually engaged with as opposed to receiving profound deliberations as to how this might influence our orientations and allegiance to the decolonisation project.

It is difficult to lead firm evidence of how clandestine reactionary groupings such as university alumni influence and shape senior university management appointments. That the Dopper Kerk has had an influence at North-West University is a "public" secret, and that the resistance and outcry from affluent benefactors in response to the recent appointment of an African female into a senior leadership position at the University of Cape Town was a telling, overt racist stance that quietly blew over, are brazen instances of contemporary fissures which are present. Institutional racism in South Africa is well documented in the literature (Jansen 2009), and refers to a situation where disadvantage is intentionally and consciously structured 
into political, social and economic systems. Conscious and subconscious prejudice is influenced by the intensity and longevity of institutional racism.

Žižek (2011) holds that arguably the most racist act is that of patronisingly elevating the status of the "other". He warns that we need to guard against what he refers to as fake multiculturalism. He also draws attention to the "fakeness" and ambiguity of political correctness, where we err on the side of false congeniality at the expense of laying bare, with a primal rawness, the uncomfortable "truths" that lurk beneath the surface. Xenophobia and tribalism are still very much a feature of particularly those HEIs that were located in the former "bantustans" of apartheid South Africa. There are real stories of cronyism, and open resentment by local students and academics of foreign nationals (both academics and students) (Dansoh 2018), yet elements of these very students belong to the same cohort which demands transformation and a decolonised curriculum.

Another somewhat disturbing example of a clandestine in-group's betrayal of their commitment to the decolonisation and transformation project of the nation, was the sentiment (whispered in hushed tones at the SAERA 2017 conference) that certain "elitist" academics (from former privileged establishments) threatened to exit and not return to this country's foremost education conference (SAERA), as they believed that they were not achieving sufficient academic "nourishment" from what they perceived as a conference dominated by young and inexperienced researchers (Master's and doctoral students). This is an intriguing stance that necessitates some analysis, as it reflects on these individuals' commitment to the national transformation agenda: in a country where research capacity and competence development has been signalled as a strategic initiative that might advance the development of the nation and its people (Academy of Science of South Africa 2010), for some academics this is clearly not a priority. This was a particularly ironic sentiment, given that the 2017 conference theme had a strong social justice and redress focus. It begs the question as to which is the more appropriate audience to whom they would prefer to disseminate the high-level knowledge they produce on how to advance South African education?

While this critical incident might be deemed anecdotal and impossible to verify, I have chosen to report it here as it is precisely these kind of in-group discourses that the "powerful" have been able so casually to get away with. This kind of "open" fakeness is what Žižek reminds us to be wary of, since it will stifle transformative initiatives. It also raises the question as to the future form and shape of SAERA conferences as spaces that offer the necessary "nourishment" to the "elite" academics, as well as creating an ethos and culture where the elite also begin to see their roles as offering nourishment to a bottom-heavy South African academic fraternity that now comprises colleagues from previously marginalised communities. In 
extending this argument, it is apparent that in the contemporary South African context neoliberal capitalism is infused and layered with a pernicious, toxic mix of racism, gender, and a multitude of other prejudices - new black capitalists and old white capitalists, and international capital power brokers. A palpable contemporary manifestation is economic apartheid - a case of inclusive exclusion at its best!

In returning to the subjects that must give effect to the decolonisation project, a question worth posing is whether decolonisation is essentially about what is in each of our heads. Should the point of departure be the university curriculum or our own psychosocial make-up (our own contaminations)? A caution worth sounding is an awareness of how bona fide misogynists, racists and xenophobes in our society expediently manipulate decolonisation discourses and projects.

How then do South African academics manage to negotiate and traverse this precariously slippery social space, one in which discourses of decolonisation and transformation are injudiciously peppered with deep-seated racist antagonisms against black South Africans? Utterances and practices range on a continuum from overt outbursts and unashamed declarations of contempt, and dominative racism characterised by enactment of bigoted dispositions, to sympathetic dispositions towards black people but simultaneous harbouring of negative attitudes and feelings towards them. The former is easy to identify - an "angry knowledge" (Jansen 2009) that takes the form of outspoken aggression, speaking forcefully and often without invitation. Varying shades of the latter thrive under an elusive and subtle facade of congeniality that masks conscious and unconscious aversion to black people. Gaertner and Dovidio $(2005,618)$ introduce the concept "aversive racism", which is "a subtle, unintentional form of bias that can have pernicious effects ... contemporary ... insidious, manifestation of racial bias". Aversive racism develops as a result of socio-cultural processes such as the "creation" of "in-groups", arrangements that are the fertile grounds for racial bias and stereotypes (Gaertner and Dovidio 2005, 621). Aversive racists are consciously aware of the need to be non-prejudiced; they may openly support equality, especially in contexts where social norms make prejudiced commentary immediately apparent or revealing. In in-group contexts where the norms are altered in terms of what are acceptable boundaries of discourse, people drop their guard. I have personally experienced/witnessed the looseness of speech, even in social gatherings, of university academics where the "we" and "them" discourse is prevalent.

Gaertner and Dovidio note that discrimination is more likely to be expressed in contexts where the "norms of appropriate behavior are weak or ambiguous ... implicit attitudes and stereotypes ... function in an unconscious and unintentional fashion" (Gaertner and Dovidio $2005,624)$. The discriminatory substance of conversations takes on such normality that its 
prejudiced implications are not brought into contention. Gaertner and Dovidio (2005, 624) assert that "... if aversive racists are unaware of their negative implicit attitudes, they may also be unaware of how their behaviours in interracial interactions may be influenced by these racial attitudes". Such practices are catalysed and reified by a culture of what Jansen $(2009,110)$ explains as “... exaggerating every conceivable problem in the new South Africa: violence, falling educational standards, problems of discipline, ... and a (black) government that needs prayer and awakening to the many ills of society". Critique of the State often carries a racial subtext. As can be expected, South Africans continue to hold onto memories of the past; such memories are infused with what Jansen describes as "knowledge in the blood" (Jansen 2009, 1). He argues that knowledge transmitted to the second generation is underlined by the belief systems that carry this knowledge: "Knowledge does not transmit as neutral, technical, factbased information from one generation to the next; it is embedded within dominant belief systems that give knowledge meaning, emotion and authority" (Jansen 2009, 60). Intergeneration transfusion of prejudice appears to have a strengthening heartbeat in the higher education community.

In comparison to our South American counterparts, where the debates have matured and conceptual richness has emerged in the literature and theory, South Africa appears to emerging from two decades of slumber. A nuanced distinction between decolonisation and decoloniality and colonisation and coloniality has evolved (see Grosfoguel 2007, 2009; De Oliviera 2011; Bhambra 2014; Maldonado-Torres 2007). So the local debates appear to be in their "infancy", and still somewhat rudimentary. To their credit, several leading academics have secured special editions of local education journals themed around the issue of decolonisation. While the revival can be viewed as a deliberative step in advancing the debate and conceptualisations, it has however been more a reaction to the groundswell of student insurrection as opposed to an organic, ongoing and sustained deliberation on a phenomenon (colonisation) that has taken root for centuries, and whose norms and value systems and world views have been "genetically" etched into our - the colonised - collective blueprint.

That we are locked into remaining colonised beings in powerfully entrenched colonial superstructures, including that of discourse (ways of being, thinking, seeing and living), makes the task of rupture from within pessimistically unattainable. This is a reminder of Rosa Luxemborg's comment that it might well be a futile effort to attempt to deconstruct the mansion of the oppressor with his very implements (Kautzer 2015). However, she makes another, equally profound comment that agentic manoeuvres usually lay bare our constraints; those who do not act (move) do not notice their chains. This is a telling assessment of how the debates and decolonisation initiatives should proceed, namely, from a position of recognising the "chains" 
as we attempt to "move". Importantly, it draws attention to the fact that there are definite and distinct powerful chains - and not flimsy cotton threads - and that these chains might suffocate our efforts and our attempt to "breathe".

Hence naive, knee-jerk reactions from university bureaucrats who speak the progressive discourse within the realms of well-circumscribed neoliberal discourses, is likely to fracture and unravel. Arguably the most salient critique of a performance approach to the decolonisation project is its assumption that the outcomes of any decolonisation effort can be predetermined, carefully plotted and measured. A fetishistic disavowal (Žižek 2011) ensues, with illusions of grandeur as to what managers profess they can achieve. Energy is expended in much pseudoactivity, such as corporate style protocols duly instituted to monitor the implementation of the decolonisation agenda. Line managers subsequently request evidence and details of the decolonisation initiatives they have applied from their subordinates.

The University of KwaZulu-Natal (UKZN) (the institution at which I am employed) in its attempt at addressing the broader social justice agenda has taken on a peculiar and intriguing position in recent times, almost "confessing" to having a handle on the issue of race and gender, and that it was time to tackle the task of "transformation" of the pedagogy. The inference here is that it seems as if university management believe that they have finally got their numbers right in terms of the university's employment equity profile, so the time has come to focus on how to teach. There are two distinct tensions with this. One is that a mere number count of race and gender trivialises the less overt and repressive prejudice that exists as it relates to both race and gender at UKZN, a phenomenon that may also be quite pronounced in several institutions across the country. The second is a somewhat superficial belief that improved teaching is likely to yield the transformation project. While improved teaching competence might well improve student throughput, it does not guarantee that the broader social justice project as it relates to decolonisation and transformation will transpire.

What is missing from the pedagogy debates is a more sophisticated understanding that the social justice project necessarily demands a deeper conceptual understanding of the principles of critical pedagogy as envisaged by the Critical School (see Giroux 2004; 2009; hooks 1994; 2009; McLaren 2003; Freire 1998).

\section{THE STUDENT AGENDA}

A defining feature of the student body is that it is never a static entity, especially its leadership, as it relates to the multifocal aspirations that different sub-constituencies pursue. These aspirations are often buoyed by power brokers who stoke infernos across the higher education context. In a country where economic resources are at a premium, flagrant disregard for 
property of public institutions is a scourge that appears to have become the culture of contemporary student politics (Jansen 2017). Impunity has become a natural state of affairs. Students' demands for immediacy of action (immediate material/survival needs) versus the inertial lethargy of both the State and HEIs to respond to students' needs is a reality that continues to plague the South African higher education context.

That sophisticated understandings of the decolonial project as it relates to curriculum and pedagogy is "absent" or rudimentary at best is an issue that is worth pursuing. So where or in which spaces do these debates happen? How are these debates likely to play themselves out in a context where students in the main might have acquisition of the knowledge package (the degree) as their primary goal, and not the emancipatory project. Accessing the economy has particular gravitas in the South African context, which is plagued by perennial high unemployment and poverty and destitution; thousands of students, trapped in poverty, aggressively seek out tertiary education as a means to access the economy.

The ultimate aspiration for middle-class status in economic society is an understandable objective (Haywood, Jenkins, and Molesworth 2011), but one that is seldom enunciated. The rhetoric of a decolonised education is louder, but it necessarily has to be one that should position "me" to secure a higher economic and social status. It becomes evident then that higher education exists as a capitalist commodity and that decolonising initiatives are necessarily circumscribed within this utilitarian objective. Higher education develops such offerings in response to what clients deem as having utility value in the marketplace - encapsulating knowledge with an exchange value. Much has been written about the commodification of education, with some critics suggesting that actually HEIs have made a bad job of this (Stronach 2010). However, the point is that higher education in developing and designing new marketresponsive curricula necessarily has the market as first master - failure to do so will render their offerings obsolete. One might argue then that extent of transformation and decolonisation has to be circumscribed in terms of what the market dictates.

Other pertinent questions begin to emerge. How do we understand an HEI as an economic unit - as a value-creating unit, as employing factors of production - as producing outputs? What choices might institutions make in determining what might constitute a producible and marketable product? How might decolonised content dilute such products' value/demand (or even increase it)? How might higher education institutions select its key factor of production (human resource/labour) so as to create the appropriate product for the market where neoliberal global ranking machinery has now established a firm foothold? A key sobering fact is a decolonised curriculum is not on the weighted index in the determination of an institution's ranking. The reality is that it is not even on the radar. This calls for a more sophisticated 
interrogation of how these contradictory value positions intersect and where they are likely to unravel.

\section{A CONCLUDING ANALYSIS ON THE "STATE OF THE ACADEMIC NATION"}

How then might we consider a deliberative dialectical reasoning/thinking that might render a level of comfort with a state of perennial dissonance, a state in which we constantly reflect on both contradiction and opportunities for integration, where we are likely to remain permanently in liminal spaces, and where as we approach what we might have believed were the pre-plotted co-ordinates of our decolonisation endeavours we realise and accept that the contours of the terrain have also altered, thus demanding a new plotting. It is no coincidence that more than 50 years after the death of Franz Fanon decolonisation remains elusive, largely because in the South African context deep-seated prejudicial orientations remain skilfully veiled. Such prejudiced orientations, utterances and actions are alive and dynamic in what I coin the "inner circles of discourse", a discursive practice that if unchecked is likely to threaten attempts at the decolonisation project in South Africa. This discursive practice remains powerful, subtle and ubiquitous, and as such has the potential for perennial perpetuation. The challenge then is how to unlock this alienating harness that threatens to keep the South African higher education community captive.

Edward Said, postcolonial theorist and world-renowned agent provocateur, urges the notion of "speaking truth to power" (Said 1985). How then do we speak truth to powerful discourses? I posit that a first step in the disruption of these discourses is the acknowledgement that deep fractures do in fact exist. How then might we disambiguate the contradictions and expose the subtext of what appears normal and acceptable? What do the guardians and custodians of new knowledge (the academic community, journals, publishing houses, regulatory bodies) want? How does decolonised knowledge get published? In the current manner in which knowledge gets vetted (peer review processes), to what extent will key gatekeepers of disciplinary knowledge boundaries validate knowledge-generation processes that do not conform/comply with traditional Western protocols for knowledge authentication and verification?

I conclude this article with an interesting analysis offered by Žižek of the impending apocalypse. He draws on Elizabeth Kubler-Ross's theory for explaining the five stages of grief (Žižek 2011). I want to use this to attempt to make sense of where we are in our grief as we attempt the decolonising and transformation project.

The first stage is denial - where we simply refuse to accept the fact that decolonisation and transformation as we would want to see it work, is just not going to happen - that certain 
obfuscations would render the debate a miasma, a murkiness, and that the neoliberal tide is too strong. The second stage is anger, which detonates when we can no longer deny that we are in fact helpless to make profound changes that we may want to measure. The third stage is bargaining, where we engage in pseudo-activity. We try to fulfil the urge to be active and participate in mindless activity so as to mask the nothingness of what goes on, a milieu where reality becomes fiction and fiction becomes the reality. Stage four is the state of depression, which is a state of libidinal disinvestment, a withdrawal from the scene; we come to the realisation that this decolonisation is not going to happen, so why bother. The last stage, acceptance, sees us recognising that we cannot fight this impending failure, so we may as well prepare for it. Žižek refers to this as an emerging emancipatory subjectivity, noting that the emancipatory turn only happens once the traumatic truth is fully lived. It marks the start of a new beginning (Žižek 2011), of relinquishing the idea of returning to some nostalgic roots but instead creating a new way of thinking about social agency.

\section{REFERENCES}

Arendt, A. 1973. The origins of totalitarianism. New York: Harcourt Brace Jovanovich.

Academy of Science of South Africa. 2010. The PhD Study: An evidenced-based study on how to reach the demands for high-level skills in an emerging economy. Pretoria: Academy of Science of South Africa.

Bhambra, G. K. 2014. Postcolonial and decolonial reconstructions. London: Bloomsbury Academic.

Bond, P. 2011. What is radical in neoliberalist-nationalist South Africa? Review of Radical Political Economics 43(3): 354-360.

Bond, P. 2014. Elite transition: from apartheid to neoliberalism in South Africa. London: Pluto Press.

Dansoh, W. 2018. The provision of Library research Support to postgraduate students: Perspectives of key stakeholders in a tertiary institution: A case study. (unpublished thesis)

De Oliviera, Andreotti V. 2011. (Towards) decoloniality and diversality in global citizenship education. Globalisation, Societies and Education 9(3-4): 381-397.

Foucault, M. 2001. Fearless speech. Edited by J. Pearson. New York: Semiotext.

Freire, P. 1998. Pedagogy of freedom: Ethics, democracy and civic courage. New York: Rowman and Littlefield Publishers.

Gaertner, S. L. and J. F. Dovidio. 2005. Understanding and addressing contemporary racism: From aversive racism to the Common Ingroup Identity Model. Journal of Social Issues 61(3): 615-639.

Giroux, H. A. 2004. Critical pedagogy and the postmodern/modern divide: Towards a pedagogy of democratization. Teacher Education Quarterly 31(1): 31-47.

Giroux, H. A. 2009. Critical theory and educational practice. In The critical pedagogy reader, ed. A. Darder, M. P. Baltodano and R. D. Torres, 27-51. New York: Routledge.

Grosfoguel, R. 2007. The epistemic decolonial turn: Beyond political economy paradigm. Cultural Studies 21(3): 203-246.

Grosfoguel, R. 2009. A decolonial approach to political-economy: Transmodernity, border thinking and global coloniality. Kult 6 Special issue. 
Habib, A. 2013. South Africa's suspended revolution: Hopes and prospects. Johannesburg: Wits University Press.

Harvey, D. 2007. A brief history of Neoliberalism. Oxford: Oxford University Press.

Harvey, D. 2008. The right to the city. New Left Review 53: 23-40.

Harvey, D. 2010a. The enigma of capital. London: Profile Books Limited.

Harvey, D. 2010b. Social justice and the city. London: University of Georgia Press.

Haywood, H., R. Jenkins and M. Molesworth. 2011. A degree will make your dreams come true: Higher education as the management of consumer desires. In The marketisation of higher education and the student as consumer, ed. M. Molesworth, R. Scullion and E. Nixon, 183-195. London: Routledge.

hooks, b. 1994. Teaching to transgress: Education as the practice of freedom. New York: Routledge.

hooks, b. 2009. Confronting class in the classroom. In The critical pedagogy reader, ed. A. Darder, M. P. Baltodano and R. D. Torres, 135-141. New York: Routledge.

Jansen, J. D. 2009. Knowledge in the blood: Confronting race and the apartheid past. Cape Town: UCT Press.

Jansen, J. D. 2017. As by fire: The end of the South African university. Cape Town: Tafelberg.

Kautzer, C. 2015. Radical philosophy: An Introduction. New York: Routledge.

Maldonado-Torres, N. 2007. On the coloniality of being: Contributions to the development of a concept. Cultural Studies 21(2-3): 240-270.

McLaren, P. 2003. Critical pedagogy and class struggle in the age of neoliberal globalization: Notes from history's underside. Democracy and Nature 9(1): 91-105.

Oloyede, O. 2009. Critical reflection on the report of the Ministerial Committee on Transformation, Social Cohesion and the Elimination of Discrimination in Public Higher Education. Perspectives in Education 27(4): 426-434.

Pogge, T. 2010. Politics as usual: What lies behind the pro-poor rhetoric. Cambridge: Polity Press.

Said, E. W. 1985. Orientalism. Harmondsworth: Penguin.

Shore, C. 2010. Beyond the multiversity: Neoliberalism and the rise of the schizophrenic university. Social Anthropology 18(1): 15-29.

Stronach, I. 2010. Globalizing education, educating the local. London: Routledge.

Zizek, S. 2008. The sublime object of ideology. New York: Verso.

Žižek, S. 2011. Living in the end times. London: Verso. 